\title{
Questions of informal caregivers of children regarding the postoperative period of cochlear implant
}

\author{
Dúvidas de cuidadores informais de crianças referentes ao pós-operatório de implante coclear \\ Dudas de cuidadores informales de niños en torno al posoperatorio de implante coclear
}

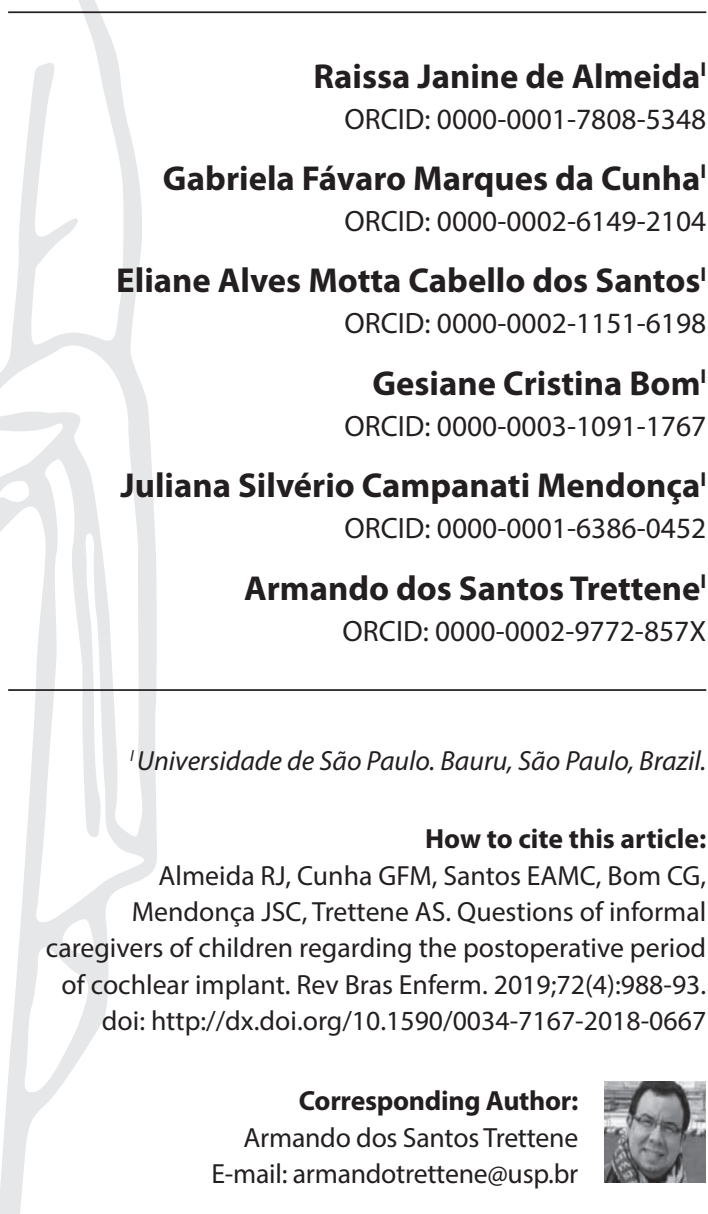

Submission: $08-07-2018$
Approval: 10-20-2018

\begin{abstract}
Objective: To identify the main questions of informal caregivers of children with hearing impairments on the postoperative care of cochlear implant. Method: Cross-sectional study developed in a public and tertiary hospital of the state of São Paulo, Brazil. The sample consisted of 48 informal caregivers who were monitoring children subjected to cochlear implant. Data collection took place during the preoperative nursing consultation, by structured interview, between September 2016 and July 2017. The questions identified were categorized by similarity. Results: The questions were related to: rest, dressing, feeding, length of stay, system activation time, infection, removal of stitches, bleeding, medicines, immediate sound stimulation, and pain. Conclusion: The prevalent questions were about rest, dressing, and feeding, and identifying them made it possible to plan and implement a nursing care aimed at the caregiver needs, as well as prepare them for care maintenance after hospital discharge.

Descriptors: Hearing Loss; Cochlear Implant; Caregivers; Postoperative Period; Nursing.
\end{abstract}

\section{RESUMO}

Objetivo: Identificar as principais dúvidas de cuidadores informais de crianças com deficiência auditiva sobre os cuidados pós-operatórios de implante coclear. Método: Estudo transversal desenvolvido em um hospital público e terciário do interior de São Paulo, Brasil. A amostra constou de 48 cuidadores informais que se encontravam acompanhando crianças submetidas a implante coclear. A coleta de dados ocorreu durante a consulta de enfermagem pré-operatória, por meio de entrevista estruturada, entre setembro de 2016 e julho de 2017. As dúvidas identificadas foram categorizadas por similaridade. Resultados: As dúvidas relacionaram-se a: repouso, curativo, alimentação, tempo de internação, tempo de ativação do sistema, infecção, retirada de pontos, sangramento, medicações, estímulo sonoro imediato e dor. Conclusão: As dúvidas prevalentes relacionaram-se ao repouso, curativo e alimentação e identificá-las possibilitou planejar e implementar uma assistência de enfermagem voltada às necessidades da clientela, além de prepara-los para manutenção dos cuidados após a alta hospitalar.

Descritores: Perda Auditiva; Implante Coclear; Cuidadores; Período Pós-Operatório; Enfermagem.

\section{RESUMEN}

Objetivo: Identificar las principales dudas de cuidadores informales de niños con discapacidad auditiva en torno a los cuidados posoperatorios de implante coclear. Método: Estudio transversal realizado en un hospital público y terciario del interior de São Paulo, Brasil. La muestra constó de 48 cuidadores informales que acompañaban a niños sometidos a implante coclear. La recolección de datos se hizo durante la consulta de enfermería preoperatoria, por medio de entrevista estructurada realizada entre septiembre de 2016 y julio de 2017. Las dudas identificadas se categorizaron por similitud. Resultados: Las dudas estuvieron relacionadas con: el reposo, el vendaje, la alimentación, el tiempo de internación, el tiempo de activación del sistema, la infección, la retirada de puntos, el sangrado, las medicaciones, el estímulo sonoro inmediato y el dolor. Conclusión: Las dudas más predominantes fueron en torno al reposo, al vendaje y a la alimentación, e identificarlas posibilitó planificar e implementar una asistencia de enfermería orientada a las necesidades de la clientela, además de prepararla para mantener los cuidados tras el alta hospitalaria. Descriptores: Pérdida Auditiva; Implantación Coclear; Cuidadores; Periodo Posoperatorio; Enfermería. 


\section{INTRODUCTION}

Hearing loss $(\mathrm{HL})$ in childhood is singled out, among the communication disorders, as one of the main causes of delayed language and speech development. It is characterized by the decreased ability to perceive sounds and can occur in varying degrees, ranging from mild to severe ${ }^{(1)}$.

With high prevalence mainly in childhood, $\mathrm{HL}$ is considered a public health problem ${ }^{(2)}$. In addition to functional changes, it can cause psychosocial problems not only to the children, but to their parents, caregivers, and family members ${ }^{(3)}$. In Brazil, its general incidence is $1.1 \%$. Of these, $21 \%$ have a severe or very severe degree of loss ${ }^{(4)}$.

Technological advancement has contributed substantially to improve the early and accurate diagnosis of HL. Among the treatment modalities, though costly, the cochlear implant $(\mathrm{Cl})$ stands out as one of the available resources. Its eligibility and effectiveness is consolidated for the treatment of people with a deep and/or severe degree of $\mathrm{HL}^{(5-6)}$.

The $\mathrm{Cl}$ is a biocompatible and durable external electronic component, located behind the ear, with the function of capturing, processing, and encoding sound energy and transmitting it to a receiver via radio frequency. In addition to this, it has a device composed of an electrode beam surgically implanted in the cochlea, whose function is electrically stimulating the cochlear nerve fibers, performing the function of the missing or damaged auditory cells. From the stimulation of the cochlear nerve, the impulses spread to the auditory cortex ${ }^{(7)}$. The use of $\mathrm{Cl}$ has been associated with better quality of life for patients and their family members ${ }^{(8)}$.

The postoperative care of $\mathrm{Cl}$ surgery include, among others, the prevention of bleeding, pain control, feeding and hydration, physical restraint, and wound care ${ }^{(9)}$. The postoperative period has also been appointed as an adequate moment to train parents or caregivers about surgery-related care, aimed at maintaining it even after hospital discharge ${ }^{(10)}$.

From the exposed, we ask: what are the main questions of informal caregivers of children with $\mathrm{HL}$ about the postoperative care of $\mathrm{Cl}$ ?

The nurse, by identifying the questions of caregivers about such care, directs it to their real needs and obtains subsidies to plan and implement educational actions aimed at minimizing complications, facilitating the process of rehabilitation, and reducing costs to the health system. We highlight the scarcity of publications related to this topic, factor that justifies the realization of this study.

\section{OBJECTIVE}

To identify the main questions of informal carers of children with $\mathrm{HL}$ about the postoperative care of $\mathrm{Cl}$.

\section{METHOD}

\section{Ethical aspects}

The research was approved by the Research Ethics Committee of the institution in 2016, by opinion no. 1792541 and CAAE no. 60745216.0.00005441. All the participants signed the informed consent form. In short, all provisions of Resolution no.466/2012 of the National Health Council on research involving humans have been observed.

\section{Study design, location, and period}

This is a descriptive, cross-sectional, and quantitative study, guided by the STROBE tool, developed between September and December 2016 and July 2017, in a public and tertiary hospital specialized in the treatment of patients with craniofacial anomalies and related syndromes, including children with $\mathrm{HL}$. It is an institution maintained with funds from the Brazilian Unified Health System and the University of São Paulo. It has 91 beds. Its service is internationally recognized for its interdisciplinary and humanized nature. It is located in the interior of the state of São Paulo, Brazil.

\section{Population, sample, inclusion and exclusion criteria}

The population was composed of informal caregivers of children with $\mathrm{HL}$ who were hospitalized for $\mathrm{Cl}$ surgery. Considering the period stipulated for the realization of this study and the average monthly surgeries, the sample consisted of 48 participants.

Inclusion criteria were: being the main and informal caregiver; accompanying the child subjected specifically to unilateral $\mathrm{Cl}$; being aged 18 years or older; and adhering voluntarily to the research. Caregivers of children with $\mathrm{HL}$ associated with other comorbidities, such as neuropsychomotor impairment, genetic and/or clinical syndromes, or other malformations or comorbidities, were excluded.

\section{Study protocol}

Data collection took place during the preoperative nursing consultation that occurs about one to two hours before the surgical procedure, being performed exclusively by the first author and advisor of this study. During this consultation, the nurse addressed aspects related to the preparation of the patient for the procedure, including: verifying the start time of fasting and its maintenance; general state of the patient; complications in the past 24 hours, previous diseases; use of medicines; need for medical evaluation, expectations about the surgical procedure; and main questions related to the postoperative period.

Structured interview was used for data collection. Initially, information about the procedure, such as indication, average surgery time, and anesthesia aspects, were provided. Later, caregivers were asked about their questions, which were written and printed by the researchers.

The questions were organized into categories, to facilitate the presentation of results. This categorization took place by similarity, i.e., after the questions were identified, they were organized according to the subject addressed, e.g., dressing, which included the way it should be done, the materials required, and the frequency of change.

The interviews took place in a private room, individually, and lasted about 20 minutes. Caregivers were also characterized according to the variables: sex, age, schooling, socioeconomic classification $^{(11)}$, and degree of kinship.

\section{Analysis of results and statistics}

The questions were written in a form made by the researchers and subsequently categorized by similarity. The questions identified were 
clarified by researchers during the consultation, and the analysis of possible correlations between the questions and the variables was not considered because caregivers did nit have previous experience regarding the postoperative care of the $\mathrm{Cl}$ surgery.

Microsoft Excel 2010 was used to tabulate and categorize the main questions. To prepare the results, the data were submitted to descriptive statistical analysis.

\section{RESULTS}

A total of 48 caregivers, with average age of 32 years ( \pm 6.5$)$, took part in the research. Most were women (89\%), with complete high school (44\%), and of low socioeconomic class (56\%). Concerning the degree of kinship, $78 \%$ of them were the mothers (Table 1).

The categories of questions of caregivers about postoperative care of $\mathrm{Cl}$ surgery were related to rest (78\%), dressing (56\%), and feeding (38\%) (Table 2).

Table 1 - Sociodemographic characterization of caregivers, Bauru, São Paulo, Brazil, 2017

\begin{tabular}{lc}
\hline \multicolumn{1}{c}{ Variables } & $\mathbf{n}(\%)$ \\
\hline Sex & \\
Female & $43(89)$ \\
Male & $5(11)$ \\
Schooling & \\
$\quad$ Complete High School & $21(44)$ \\
Complete Higher Education & $11(22)$ \\
Incomplete Higher Education & $5(11)$ \\
Complete Elementary School & $5(11)$ \\
Incomplete Elementary School & $3(6)$ \\
Incomplete High School & $3(6)$ \\
Socioeconomic classification & \\
Superior Low & $26(56)$ \\
Inferior Low & $11(22)$ \\
Inferior Middle & $11(22)$ \\
Degree of kinship & \\
Mother & $38(78)$ \\
Father & $5(11)$ \\
Grandmother & $5(11)$ \\
\hline
\end{tabular}

Table 2 - Distribution of questions of caregivers about postoperative care of cochlear implant surgery, Bauru, São Paulo, Brazil, 2017

\begin{tabular}{lc}
\hline \multicolumn{1}{c}{ Questions } & $\mathbf{n}(\%)$ \\
\hline Rest & $38(78)$ \\
Dressing & $26(56)$ \\
Feeding & $18(38)$ \\
Length of stay & $18(38)$ \\
System activation time & $18(38)$ \\
Infection & $11(22)$ \\
Removal of stitches & $11(22)$ \\
Bleeding & $11(22)$ \\
Medicines & $11(22)$ \\
Immediate sound stimulation & $8(16)$ \\
Pain & $5(11)$ \\
\hline
\end{tabular}

\section{DISCUSSION}

Regarding the sociodemographic characterization, women were prevalent, since most were the mothers. Different studies have pointed the prevalence of mothers as the main caregivers of children ${ }^{(10,12)}$.
The benefits of the maternal presence during hospitalization include strengthening the bond with the child, improving the response to treatment, minimizing stress, and training for the postoperative care. In this context, mothers go from spectators to collaborators, providing, along with the nursing staff and other health professionals, a holistic and more humanized care ${ }^{(10)}$. In addition, the maternal presence allows nurses and their team to identify questions about the care, thus promoting their teaching ${ }^{(13)}$.

It also contributes to keep the child calm and collaborative, since they have a consolidated communication standard. Since mothers know their children, they contribute in the identification process of postoperative pain and other signs and symptoms, including complications ${ }^{(9)}$. Thus, their presence is crucial and indispensable.

Concerning the schooling of participants, complete high school prevailed. It is believed that the higher the schooling, the greater the understanding and, thus, the search for information regarding treatment modalities and the care for the child ${ }^{(12)}$.

The diagnosis of $\mathrm{HL}$ requires parents to take a series of decisions, including the choice of treatment. One must search for different shapes and patterns of communication and education, which are not always available or accessible to all $^{(14)}$. Thus, it is believed that having higher schooling facilitates this process, since parents and caregivers tend to know and seek their rights related to treatment and accessibility ${ }^{(12)}$.

Several aspects have affected the decision-making process of parents concerning the cochlear implant of their child, including the quality, quantity, and diversity of information received; prior knowledge about $\mathrm{Cl}$ and deafness; expectations for the development of oral and gestural language; bioethical aspects; preserving residual hearing due to expectation of development of new technologies; restrictions on daily activities, $\mathrm{Cl}$ effectiveness; care and financial costs with the device; and postoperative rehabilitation $^{(14)}$.

Although the $\mathrm{Cl}$ restores the opportunity for the children to hear, favoring their personal, social, and academic development, even after the surgery they continue to experience difficulties, requiring the mobilization of the family to succeed ${ }^{(15)}$.

Regarding the socioeconomic level, lower class individuals prevailed. A similar result was observed in another research ${ }^{(9)}$. $\mathrm{Cl}$ is a costly procedure and, in the case of a population short of resources, public institutions must be sought to offer the full treatment. The low-income population is more affected by hearing loss, because of the lack of access to prevention and health care and the financial incapacity to purchase and maintain adequate prostheses $^{(16)}$.

Concerning the questions about the postoperative period of $\mathrm{Cl}$ surgery, the category of rest prevailed. The caregivers questioned about what activities could be conducted after the surgery, such as playing and going to school. During the immediate postoperative period, particularly in the first hours after the surgical procedure, complete rest is required, since structures responsible for balance are manipulated during the surgery, which can lead to dizziness and, consequently, falls ${ }^{(9)}$. Also, the use of anesthetics often causes drowsiness or change in behavior, including unrest. There is also the fact that children are more prone to fall, increasing the incidence of traumas, length of stay, and total costs ${ }^{(17-18)}$. 
It is recommended that, after discharge, the children remain in relative rest for 15 days, i.e., they can move as long as they avoid greater physical efforts. They must avoid, in this period, games that may result in falling or trauma to the surgical site, such as running or playing with balls. It is also contraindicated for the child to lie or sleep on the side that was operated ${ }^{(9)}$.

In this context, this study pointed out that the parents, to avoid damage to the child's implant, restrict certain sporting and recreational activities. They often delimit places, activities, and the age range of the children and people they can interact with. Thus, the child often interprets such actions as unjust rules and impositions ${ }^{(19)}$.

Another category of questions was related to dressings, including the way they should be done, the materials required, and the frequency of change. In our service, at the end of the surgery, a dressing consisting of a transparent film that will come off between three and five days is applied to the surgical wound. Patients are instructed to cut the edges as the film comes out, not being required changing it while adhered to the skin. Although there is no restriction to washing the hair, one must avoid wetting the dressing. Therefore, it is advisable to use the showerhead. After the total detachment of the dressing, one must only wash the site as usual.

Still, a secondary dressing with crepe bandage is used, forming a"helmet" with the purpose of compressing the surgical site, which must remain for 24 hours. However, one should avoid excessive compressions. Concerning the removal of stitches, it must occur between seven and ten days after surgery ${ }^{(20)}$. Nevertheless, according to our protocol, an adhesive liquid is used for the synthesis of surgical incision, that is, threads are not used for suture. Thus it is not necessary to remove them.

Regarding feeding, a light diet is recommended in the first few days after surgery because of the effort made while chewing. Nausea and vomiting may occur, which justify this type of diet. However, there are no restrictions after hospital discharge ${ }^{(9)}$. A recent research pointed out that postoperative patients may show changes in gustatory and olfactory functions, which might change eating habits ${ }^{(21)}$.

Another category of questions referred to postoperative infection. For caregivers, the risk of infection is only related to the surgical incision and device implementation. However, it is known that, in addition to these, there are other risk factors, such as venous access and exposure to the hospital environment. In this context, one needs to monitor signs and symptoms that may indicate infectious processes, including the presence of phlogistic signs in the surgical wound and changes in body temperature ${ }^{(9)}$.

Bleeding was also reported by caregivers. It is rare in the postoperative period of $\mathrm{Cl}$, and the most common occurrence is bruises, which require draining in some cases. But even in cases where draining is needed, the evolution is satisfactory ${ }^{(22)}$. However, precautions regarding bleeding should be performed systematically, especially in the immediate postoperative period ${ }^{(9)}$.

Caregivers have also shown concern about the medicines to be used. In fact, the postoperative period usually requires analgesics, anti-inflammatory drugs, and antiemetics. Sporadically, opioids are needed ${ }^{(9,23)}$. During hospitalization, the children remain with venous access and, depending on the food acceptance and incidence of nausea and vomiting, receiving intravenous hydration. The use of antibiotic therapy begins at the intraoperative period and must continue for seven to ten days after surgery ${ }^{(20)}$.

Regarding postoperative pain, it is important to evaluate associated with the child's vital signs, since it will be expressed by nonverbal signals. Therefore, nurses and their team should be attentive to facial expression and restlessness. However, postoperative pain is not frequent, since analgesics and antiinflammatory drugs are used systematically ${ }^{(9)}$.

Concerning the presence of sound stimuli shortly after the procedure, the device activation occurs only in the late postoperative period, specifically 30 days after surgery. Thus, there is no stimulation before this period ${ }^{(23)}$. A research has pointed out that, after eight months of $\mathrm{Cl}$ use, significant results related to auditory control linked to voice production were observed ${ }^{(24)}$.

Regarding length of stay, in the institution of this research, children stay for 48 hours. Although discharge after 24 hours is possible, staying for 48 hours allows the systematic observation of postoperative complications pertaining to this period. The most frequent postoperative complications include: dizziness, infection, suture dehiscence, bruises, facial nerve damage, meningitis, and device failure ${ }^{(20,22,25)}$. They must be ruled out before hospital discharge and monitored at home.

\section{Study limitations}

The cross-sectional design, which does not allow assessing cause and effect relationships, and the single-center nature can be regarded as limitations of this study. Thus, the conduction of multicenter and longitudinal researches is encouraged. Also, the scarcity of studies on this subject has limited the comparisons of results.

\section{Contributions to the field of nursing}

The benefits of this research are evident, especially because it disseminates the experience in the $\mathrm{Cl}$ postoperative care of children in a moment that health agencies show a great effort to decentralize and universalize services aimed at rehabilitation of HL patients. Thus, the knowledge acquired here may contribute, besides minimizing the questions of parents, family members, and informal caregivers, to provide guidance to health professionals who will meet this public.

We highlight that nursing care must begin in the preoperative period by providing guidelines and that the strengthening of the decision-making process extends to the intra and postoperative period, which includes the preparation of caregivers regarding home care ${ }^{(19,26)}$. In addition to the promotion of the quality of life of these children and their family members, the systematized nursing care contributes to minimize postoperative complications and to the success of hearing and language rehabilitation ${ }^{(27)}$.

\section{CONCLUSION}

The questions of the informal caregivers of children submitted to $\mathrm{Cl}$ surgery about the postoperative period were related to rest, pain, bleeding, infection, medicines, feeding, dressing, removal of stitches, length of stay, device activation time, and presence 
of immediate sound stimulation. However, those related to rest, dressing, and feeding prevailed.

Identifying the main questions of informal caregivers has made it possible to plan and implement a nursing care aimed at the needs of this public, as well as to minimize the stress imposed by hospitalization and prepare them to maintain the care after discharge, reducing complications and favoring the rehabilitation process of these children.

\section{REFERENCES}

1. Oliveira PS, Penna LM, Lemos SMA. Language development and hearing impairment: literature review. Rev CEFAC [Internet]. 2015 [cited 2018 Oct 10];17(6):2044-55. Available from: http://www.scielo.br/pdf/rcefac/v17n6/1982-0216-rcefac-17-06-02044.pdf

2. Ebrahimi H, Mohammadi E, Mohammadi MA, Pirzadeh A, Mahmoudi H, Ansari I. Stigma in mothers of deaf children. Iran J Otorhinolaryngol [Internet]. 2015 [cited 2018 May 26];27(79):109-18. Available from: https://www.ncbi.nlm.nih.gov/pmc/articles/PMC4409955/pdf/ijo-27109.pdf

3. Timothy BK, Tolson D, Day T, McColgan G, Kroll T, Maclaren W. Older people's views on what they need to successfully adjust to life with a hearing aid. Health Soc Care Community [Internet]. 2013 [cited 2018 Jul 11];21(3):293-302. Available from: https://www.ncbi.nlm.nih.gov/ pmc/articles/PMC3712468/pdf/hsc0021-0293.pdf

4. Instituto Brasileiro de Estatística e Geografia-IBGE. Pesquisa Nacional de Saúde-IBGE. Ciclos de vida no Brasil e Grandes Regiões: 2013[Internet]. Rio de Janeiro: IBGE; 2015[cited 2018 Jul 11]. Available from: https://biblioteca.ibge.gov.br/visualizacao/livros/liv94522.pdf

5. Grover M, Sharma S, Bhargava S, Singh SN, Gupta G, Sharma MP. Cochlear implantation in children with anomalous cochleovestibular anatomy: our experience. Indian J Otolaryngol Head Neck Surg [Internet]. 2017 [cited 2018 Jul 11];69(4):504-8. Available from: https://link. springer.com/content/pdf/10.1007\%2Fs12070-017-1209-z.pdf

6. Meredith MA, Rubinstein JT, Sie KCY, Norton SJ. Cochlear implantation in children with postlingual progressive steeply sloping highfrequency hearing loss. J Am Acad Audiol [Internet]. 2017 [cited 2018 Jul 11];28(10):913-9. Available from: https://www.ingentaconnect. com/contentone/aaa/jaaa/2017/00000028/00000010/art00005?crawler=true\&mimetype=application/pdf

7. Vieira SS, Bevilacqua MC, Ferreira NMLA, Dupas G. Cochlear implant: the complexity involved in the decision making process by the family Rev Latino-Am Enfermagem [Internet]. 2014 [cited 2018 Jul 11];3(22):15-24. Available from: http://www.scielo.br/pdf/rlae/v22n3/01041169-rlae-22-03-00415.pdf

8. Dillon MT, Buss E, Rooth MA, King ER, Deres EJ, Buchman CA, et al. Effect of cochlear implantation on quality of life in adults with unilateral hearing loss. Audiol Neurootol [Internet]. 2018 [cited 2018 Jul 11];22(4-5):259-71. Available from: https://www.karger.com/Article/ Pdf/484079

9. Pereira PJS, Souza NFH, Almeida RJ, Menezes DC, Bom GC, Trettene AS. Nursing diagnoses and interventions in children submitted to cochlear implantation. Rev Esc Enferm USP [Internet]. 2017 [cited 2018 Jul 11];51:1-7. Available from: http://www.scielo.br/pdf/reeusp/ v51/1980-220X-reeusp-51-e03238.pdf

10. Trettene AS, Razera APR, Maximiano TO, Luiz AG, Dalben GS, Gomide MR. Doubts of caregivers of children with cleft lip and palate on postoperative care after cheiloplasty and palatoplasty. Rev Esc Enferm USP [Internet]. 2014 [cited 2018 Jul 11];48(6):993-7. Available from: http://www.scielo.br/pdf/reeusp/v48n6/0080-6234-reeusp-48-06-0993.pdf

11. Graciano MIG, Souza EG, Rosa JA, Blattner SHB. Validação de conteúdo de um instrumento de avaliação socioeconômica no âmbito do serviço social. RIPE [Internet]. 2015 [cited 2018 Jul 11];19(36):29-57. Available from: http://ojs.ite.edu.br/index.php/css/article/ viewFile/214/253

12. Trettene AS, Fontes CMB, Razera APR, Gomide MR. Impact of promoting self-care in nursing workload. Rev Esc Enferm USP [Internet]. 2016 [cited $2018 \mathrm{Jul}$ 11];50(4):633-9. Available from: http://www.scielo.br/pdf/reeusp/v50n4/0080-6234-reeusp-50-04-0635.pdf

13. Trettene AS, Luiz AG, Razera AP, Maximiano TO, Cintra FM, Monteiro LM. Nursing workload in specialized semi-intensive therapy unit: work force size criteria. Rev Esc Enferm USP [Internet]. 2015 [cited 2018 Jul 11];49(6):960-6. Available from: http://www.scielo.br/pdf/reeusp/ v49n6/0080-6234-reeusp-49-06-0960.pdf

14. Hardonk S, Bosteels S, Desnerck G, Loots G, Van Hove G, Van Kerschaver E, et al. Pediatric cochlear implantation: a qualitative study of parental decision-making processes in Flanders, Belgium. Am Ann Deaf [Internet]. 2010 [cited 2018 May 26];155(3):339-52. Available from: https://www.ncbi.nlm.nih.gov/pubmed/21138046

15. Vieira SS, Dupas G, Chiari BM. Cochlear implant: the family's perspective. Cochlear Implants Int [Internet]. 2018 [cited 2018 Jul 11];19(4):21624. Available from: https://www.tandfonline.com/doi/abs/10.1080/14670100.2018.1426406?journalCode=ycii20

16. World Health Organization-WHO. Deafness and hearing impairment [Internet]. 2012[cited 2018 May 26]. Available from: http://www.who. int/mediacentre/factsheets/fs300/en/

17. Stephenson M, Mcarthur A, Giles K, Lockwood C, Aromataris E, Pearson A. Prevention of falls in acute hospital settings: a multi-site audit and best practice implementation project. Int J Qual Health Care [Internet]. 2016 [cited 2016 Jun 6];28(1):92-8. Available from: http://intghc. oxfordjournals.org/content/early/2015/12/16/intqhc.mzv113

18. Clancy A, Mahler M. Nursing staffs' attentiveness to older adults falling in residential care: an interview study. J Clin Nurs [Internet]. 2016 
[cited 2018 Jul 11];25(9-10):1405-15. Available from: https://onlinelibrary.wiley.com/doi/epdf/10.1111/jocn.13240

19. Vieira SS, Bevilacqua MC, Ferreira NMLA, Dupas G. Discovery of hearing impairment by the family: seeing an idealized future collapse. Acta Paul Enferm [Internet]. 2012 [cited 2018 Jul 11];25(Suppl 2):82-8. Available from: http://www.scielo.br/pdf/ape/v25nspe2/13.pdf

20. Theissing J, Rettinger G, Wemer JA. Técnicas cirúrgicas em otorrinolaringologia e cirurgia de cabeça e pescoço. Rio de Janeiro: Revinter; 2013.

21. Walliczek-Dworschak U, Knauer CM, Murbe D, Mainka A, Hummel T. Analysis of taste function in patients before and after cochlear implant surgery. Rhinology [Internet]. 2018 [cited 2018 Jul 11];56(2):149-54. Available from: https://www.ncbi.nlm.nih.gov/pubmed/29306957

22. Lima Jr LRP, Rodrigues Jr FA, Calhau CMD, Calhau ACDF, Palhano CTP. Postoperative complications in implanted patients in the Cochlear Implant Program of Rio Grande do Norte, Brazil. Braz J Otorhinolaryngol [Internet]. 2010 [cited 2018 Jul 11];76(4):517-21. Available from: http://www.scielo.br/pdf/bjorl/v76n4/en_v76n4a17.pdf

23. Bento RF, Lima Jr LRP, Tsuji RK, Gomez MVSG, Lima DVSP, Brito Neto RV. Tratado de implante coclear e próteses auditivas implantáveis. Rio de Janeiro: Thieme; 2014.

24. Jafari N, Izadi F, Salehi A, Dabirmoghaddam P, Yadegari F, Ebadi A, et al. Objective voice analysis of pediatric cochlear implant recipients and comparison with hearing aids users and hearing controls. J Voice [Internet]. 2017 [cited 2018 Jul 11];31(4):11-18. Available from: https:// www.sciencedirect.com/science/article/abs/pii/S0892199716302880

25. Hänsel T, Gauger U, Bernhard N, Behzadi N, Ventura MER, Hofmann V, et al. Meta-analysis of subjective complaints of vertigo and vestibular tests after cochlear implantation. Laryngoscope [Internet]. 2018 [cited 2018 Jul 11];128:2110-123. Available from: https://onlinelibrary.wiley. com/doi/epdf/10.1002/lary.27071

26. Razera AP, Trettene AS, Mondini CC, Cintra FM, Tabaquim ML. Educational video: a training strategy for caregivers of children with cleft lip and palate. Acta Paul Enferm [Internet]. 2016 [cited 11 Apr 2019];29(4):430-8. Available from: http://www.scielo.br/pdf/ape/v29n4/en_19820194-ape-29-04-0430.pdf

27. Hou JH, Zhao SP, Ning F, Rao SQ, Han DY. Postoperative complications in patients with cochlear implants and impacts of nursing intervention. Acta Otolaryngol [Internet]. 2010 [cited 2018 Jul 11];130(6):687-95. Available from: https://www.tandfonline.com/doi/pdf/10.3 109/00016480903334445?needAccess=true 